University of Nebraska - Lincoln

DigitalCommons@University of Nebraska - Lincoln

1998

\title{
4. Grain-Size Distribution and Significance of Clay and Clay-Sized Minerals in Eocene to Holocene Sediments from Sites 918 and 919 in the Irminger Basin
}

\author{
Kraig Heiden \\ University of Nebraska-Lincoln \\ Mary Anne Holmes \\ University of Nebraska-Lincoln, mholmes2@unl.edu
}

Follow this and additional works at: https://digitalcommons.unl.edu/geosciencefacpub

Part of the Earth Sciences Commons

\footnotetext{
Heiden, Kraig and Holmes, Mary Anne, "4. Grain-Size Distribution and Significance of Clay and Clay-Sized Minerals in Eocene to Holocene Sediments from Sites 918 and 919 in the Irminger Basin" (1998). Papers in the Earth and Atmospheric Sciences. 60.

https://digitalcommons.unl.edu/geosciencefacpub/60
}

This Article is brought to you for free and open access by the Earth and Atmospheric Sciences, Department of at DigitalCommons@University of Nebraska - Lincoln. It has been accepted for inclusion in Papers in the Earth and Atmospheric Sciences by an authorized administrator of DigitalCommons@University of Nebraska - Lincoln. 


\title{
4. GRAIN-SIZE DISTRIBUTION AND SIGNIFICANCE OF CLAY AND CLAY-SIZED MINERALS IN EOCENE TO HOLOCENE SEDIMENTS FROM SITES 918 AND 919 IN THE IRMINGER BASIN ${ }^{1}$
}

\author{
Kraig A. Heiden ${ }^{2,3}$ and Mary Anne Holmes ${ }^{2}$
}

\begin{abstract}
Lower Eocene to Holocene sediments recovered from Ocean Drilling Program Sites 918 and 919 were studied to determine the grain-size distribution (sand to clay sizes) and mineralogy of the $<2 \mu \mathrm{m}$ size fraction. The minerals are believed to be of detrital origin. The clay minerals consist of chlorite, smectite, illite, kaolinite, and a mixed-layer illite/smectite. Several nonclay minerals were identified as well, including quartz, plagioclase, alkali-feldspar, amphibole, pyroxene, zeolite, and calcite.

Relative abundances of the clay minerals were semiquantified using an oriented internal standard. Smectite abundances were found to increase with depth, while illite and chlorite abundances decrease with depth.

The Eocene sediments of Site 918 are characterized by a predominance of smectite with some kaolinite and very small amounts of chlorite and illite. This mineral assemblage is indicative of warm climatic conditions at the time of deposition. Oligocene sediments show an increase in chlorite and illite, suggesting that a sediment dam may have existed on the continental shelf, trapping these sediments and preventing their transport into the Irminger Basin, prior to this time. A warming trend in the early to middle Miocene is indicated by increased amounts of kaolinite. Variations in the relative amounts of chlorite and illite at this time may be the result of short-term eustatic sea level changes. Near the end of the Miocene, a cooling trend is indicated by increasing amounts of chlorite and illite relative to smectite abundance. This follows deposition of glauconitic hardgrounds at the top of a chalk unit with coarse sediment deposited above them, often with erosion of the underlying hardground. This interval is believed to coincide with the spillover of Arctic seawater into the Irminger Basin. The hardgrounds indicate hiatuses of short duration (thousands to tens of thousands of years) followed by high density turbidity currents or renewed chalk deposition. Non-clay minerals in the $<2 \mu \mathrm{m}$ size fraction become common in upper Miocene to Holocene sediments of Sites 918 and 919, as glacial rock-flour that signals the onset of Greenland glaciation. Using R-mode factor analysis, the clay assemblages of Pliocene-Pleistocene age sediments were found to be significantly different from older sediments, with a dramatic transition at $457 \mathrm{mbsf}$, recording the beginning of significant Greenland glaciation.
\end{abstract}

\section{INTRODUCTION}

Ocean Drilling Program (ODP) Leg 152 targeted basement basalt along the volcanic rifted margin of southeast Greenland. Sites 918 and 919 are located within the Irminger Basin, on the upper continental rise of the southeast Greenland margin, approximately $130 \mathrm{~km}$ and $205 \mathrm{~km}$, respectively, from the east coast of Greenland (Fig. 1). The $1189.4 \mathrm{~m}$ of sediment collected above subaerially weathered basement at Site 918 was divided into five lithologic units (Larsen et al., 1994). They range in age from early Eocene to Holocene and consist of, from the oldest upward, lower middle Eocene glauconitic silt (Unit V), middle upper Eocene volcaniclastic silt (Unit IV), upper Oligocene to lower Miocene coarse-grained turbidites (Unit III), lower upper Miocene glauconitic, silty chalk (Unit II), and upper Miocene-Holocene hemipelagic mud with fine-grained turbidites (Unit I). Ice-rafted dropstones were identified in sediment as old as late Miocene, about 7 Ma (Larsen et al., 1994; Shipboard Scientific Party, 1994a). Site 919 yielded $147.0 \mathrm{~m}$ of Pliocene to Pleistocene age sediment. The sediments were assigned to one lithologic unit correlative with lithologic Unit I at Site 918 and consist predominantly of silty clay, clayey silt, and clay with silt (Shipboard Scientific Party, 1994b).

Clay-mineral distribution in marine sediments generally reflects varying climatic zones in the clastic source areas in addition to means of transport (Biscaye, 1965; Griffen et al., 1968; Rateev et al., 1969)

${ }^{1}$ Saunders, A.D., Larsen, H.C., and Wise, S.W., Jr. (Eds.), 1998. Proc. ODP, Sci. Results, 152: College Station, TX (Ocean Drilling Program).

${ }^{2}$ University of Nebraska-Lincoln, Department of Geology, 214 Bessey Hall, Lincoln, NE 68588-0340, U.S.A. mholmes@unlinfo.unl.edu

${ }^{3}$ Present address: Baker-Hughes, 1610 St. Etienne Rd., Broussard, LA 70518. kheiden@worldnet.att.net and has been used as an indicator of paleoclimatic trends and patterns (Chamley, 1979; Singer, 1984). ODP Site 918 in the Irminger Basin offers an excellent place to test the hypothesis that clays in marine sediments are climatic indicators, because the climate in this area is known to have changed significantly from the Eocene to the Quaternary, from a warm, wet climate to the present icehouse one.

Regionally, smectite has been found to be the dominant clay-mineral component in Eocene and Oligocene age sediments in the Norwegian-Greenland Sea. This clay is generated by weathering in temperate, wet to monsoonal climates and is a common product of basalt weathering (Biscaye, 1965; Chamley, 1989). Sediments recovered during Deep Sea Drilling Project (DSDP) Leg 38 at Site 336, on the northern flank of the Iceland-Faeroe Ridge (Fig. 1), were found to contain dominant amounts of smectite throughout the hole, with as much as $90 \%$ of the clay-mineral assemblage of the Oligocene deposits consisting of a ferruginous montmorillonite (Timofeev et al., 1978). Hole 408, drilled during DSDP Leg 49 on the west flank of the Reykjanes Ridge (Fig. 1), yielded lowermost Eocene to middle Miocene sediments with nearly pure smectite making up the clay-mineral assemblage (Timofeev et al., 1979). Smectite was also found to be the major constituent of Eocene to Miocene/Pliocene sediments recovered near the Vøring Plateau at ODP Site 643 (Fig. 1; Froget et al., 1989).

In sediments recovered during ODP Leg 104 at Site 642 on the outer Vøring Plateau (Fig. 1), Krissek (1989) noted an increase in chlorite near the middle Miocene/upper Miocene boundary, which he attributed to a change from temperate and moist weathering conditions to cool, dry conditions. Evidence for North Atlantic glaciation becomes prevalent in Pleistocene and Pliocene sediments of all the aforementioned areas, in the form of ice-rafted debris and non-clay minerals in the clay size fraction (Cremer et al., 1989; Thiébault et al., 1989; Nielsen et al., 1989; Timofeev et al., 1978; 1979). 
Figure 1. Map of southeast Greenland and the Irminger Basin showing locations of regional ODP and DSDP drilling sites.

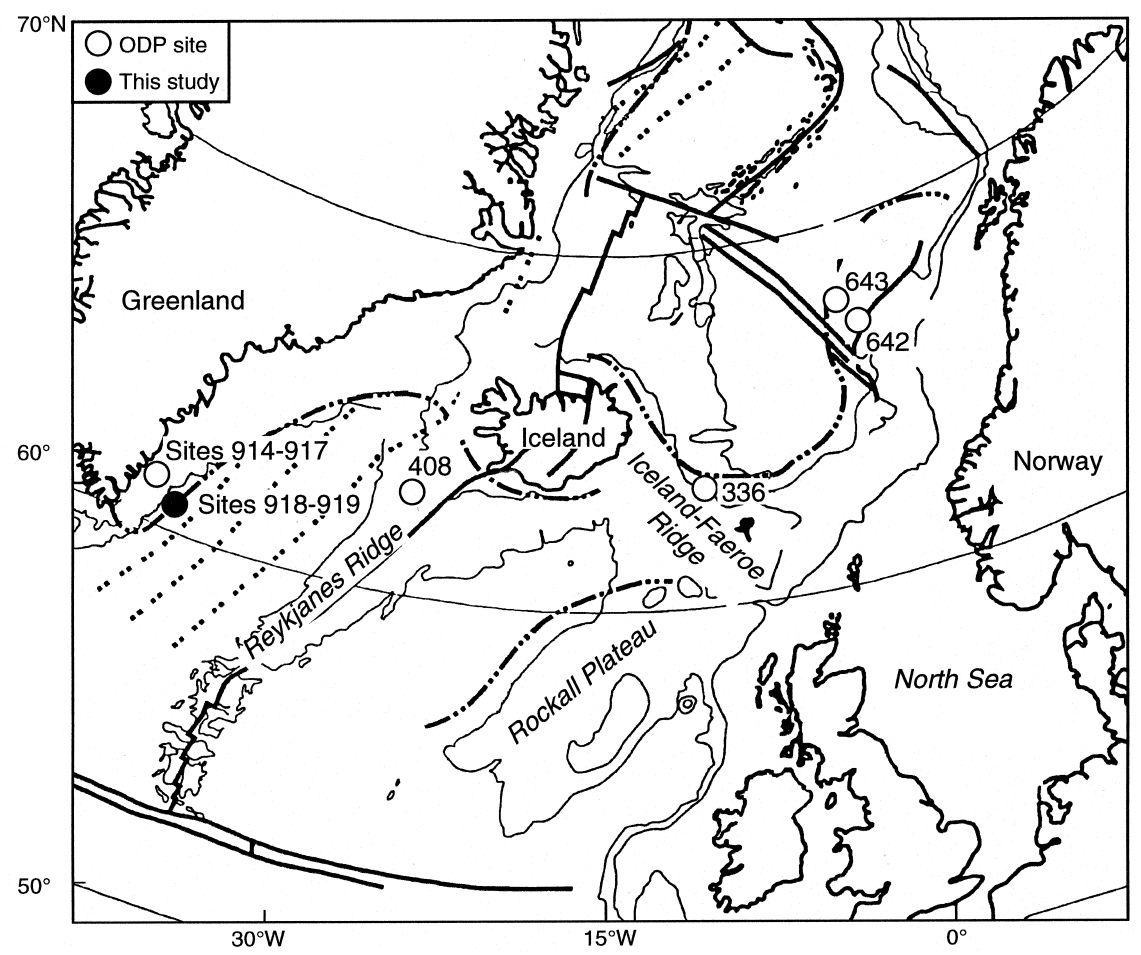

on a cumulative-frequency curve as weight percent, assuming a sample density of $2.65 \mathrm{gm} / \mathrm{cm}^{3}$.

\section{Qualitative Clay Mineral Analysis}

The samples were prepared by crushing them with a mortar and pestle and suspending a portion of the sample in filtered water. A small amount of Calgon was added to each sample solution to aid in dispersion and inhibit flocculation. The $<2 \mu \mathrm{m}$ size fraction was separated from the remainder of the sample by centrifugal acceleration using an International Size 2 Model V centrifuge (Jackson, 1975). Oriented slides of the $<2 \mu \mathrm{m}$ size fraction were prepared using the Millipore filter transfer method of Drever (1973). All slides were analyzed by X-ray diffractometry using a Scintag PAD V X-ray diffractometer with a graphite monochromator and $\mathrm{CuK} \alpha$ radiation. All slides were scanned untreated (i.e., air-dried) and after being solvated with ethylene-glycol vapor (Moore and Reynolds, 1989). Slides were than heated to $350^{\circ} \mathrm{C}$ for $1 \mathrm{hr}$ in a muffle furnace and immediately scanned. The untreated samples were scanned at a rate of $0.03^{\circ} 2 \theta$ per second from $2^{\circ}$ to $45^{\circ} 2 \theta$. The ethylene glycol solvated slides were scanned at a rate of $0.02^{\circ} 2 \theta$ per second from $2^{\circ}$ to $30^{\circ} 2 \theta$, and the heated samples were scanned from $2^{\circ}$ to $15^{\circ} 2 \theta$ at a rate of $0.03^{\circ} 2 \theta$ per second.

Minerals were identified by characteristic reflections as discussed in Brown and Brindley (1980) and Moore and Reynolds (1989). The following reflections were used for identification: the 001 reflection of smectite after ethylene glycol solvation (17.1 $\AA$ ), the 001 and 002 reflections of kaolinite at $12.5^{\circ} 2 \theta$ and $24.9^{\circ} 2 \theta$, respectively, and their response to heating. We could usually resolve the reflection at $24.9^{\circ} 2 \theta$ from its neighboring peak at $25.5^{\circ} 2 \theta$ (chlorite 004 peak) by using Biscaye's method (1964) of resolving the kaolinite/chlorite double peaks at $\sim 3.5 \AA$ by means of scanning more slowly over this area. The presence of chlorite was also confirmed by the 001 reflection at $14.2 \AA$. A reflection at $\sim 10 \AA$ will be referred to, in this study, as belonging to illite (001); however, mica also shares an identical $d$ spacing, and the two could not be sufficiently differentiated. In many samples, the full width at half maximum height for this reflection $\left(\sim 10 \AA\right.$ ) was less than $0.2^{\circ} 2 \theta$, indicating the presence of mica (Rey- 
nolds, 1980). However, the base of the peak tended to broaden and become asymmetrical when treated with ethylene glycol, indicating the copresence of expandable layers and suggesting a mixed-layer illite/smectite mineral as well.

In addition to the clay minerals, several non-clay minerals were identified in the $<2 \mu \mathrm{m}$ size fraction. They were identified by their characteristic reflections, quartz at $4.26 \AA$, feldspars at 3.18-3.21 (plagioclase) and 3.24-3.31 $\AA$ (alkali feldspars) (Borg and Smith, 1969), amphibole at $\sim 8.4 \AA$, calcite at $3.04 \AA$, and zeolite (probably clinoptilolite) at $\sim 9.1 \AA$ (Brown and Brindley, 1980; Moore and Reynolds, 1989; Mumpton, 1960).

Glauconitic hardgrounds occurring near the top of lithologic Unit II were scraped, mixed with distilled water, and allowed to dry on glass slides for scanning. Glauconite pellets and rip-up clasts in sediment above the hardgrounds were similarly prepared. Hardgrounds and pellets were X-rayed as the other samples were, including treatment with ethylene glycol.

\section{Semi-Quantitative Clay Mineral Analysis}

Relative clay-mineral abundance was estimated by using an oriented internal standard. Methods were based largely on those described by Moore and Reynolds (1989), with some modification. Talc was chosen as the internal standard because of its platy nature, which is similar to the clay species being quantified. A talc suspension was prepared (talc dispersed in distilled water), and the $<2 \mu \mathrm{m}$ size fraction was removed. The $<2 \mu \mathrm{m}$ size portion of the talc was then used to prepare a standard suspension. This standard suspension was calibrated by extracting an aliquot of known volume, using a pipette, and adding it to a weighed evaporation dish. The evaporation dish was then oven-dried, cooled in a desiccator, and weighed again. This entire process was repeated three times and an average weight for an aliquot of talc suspension was determined. In an effort to avoid differences due to settling, the suspension was continually agitated (using a magnetic stirring bar) during extraction of each aliquot. Each sediment sample suspension was then calibrated in the same way as the talc suspension, and an amount equal to $10 \%$ by weight talc was added to each sample. Oriented slides were made of each sample/talc mixture, again using the Millipore filter transfer method (Drever, 1973). These slides were then saturated with ethylene glycol vapor for $\sim 12 \mathrm{hr}$ immediately before being X-rayed.

Each slide was X-rayed from $2^{\circ}$ to $12.5^{\circ} 2 \theta$ at $0.02^{\circ} 2 \theta$ per second and from $8^{\circ}$ to $10^{\circ} 2 \theta$ and $24.5^{\circ}-25.5^{\circ} 2 \theta$ at $0.01^{\circ} 2 \theta$ per second. Relative abundances of the clay minerals were calculated from the ratios of intensities (areas) of peaks from minerals of the original sample to the intensity (area) of a reference peak of the internal standard (talc). Areas were calculated using a split Pearson equation in the Profile Fitting program of the DMS 2000 version 2.15 computer software by Scintag. The peaks used to calculate these ratios were the 001 of smectite, the 001 of illite, the 004 of chlorite, and the 002 of kaolinite as these were the only peaks not completely interfered with by peaks of other minerals and could be sufficiently resolved using the Profile Fitting program. The areas of these peaks were all compared with the 001 of talc $\left(9.4^{\circ} 2 \theta\right)$. These quantities are intended to show relative changes in the abundances of the clay-mineral species and not absolute abundance. Methods of calculations to transform analyzed intensities into quantitative values can be found in Moore and Reynolds (1989). Percentages of clay minerals were normalized to $100 \%$. A sample slide was run five duplicate times to determine the percent error caused by the machine and the operator (i.e., the defining of peaks used for area measurements using the Profile Fitting program). Percentage of errors varied with the mineral abundance and ranged from $7.7 \%$ for most abundant mineral (smectite) to $19.2 \%$ for the least abundant mineral (kaolinite). The total percentage of error was $11.7 \%$. Non-clay minerals and amorphous material were observed but not quantified.
The values obtained for relative clay-mineral abundances, using the above method, were compared to values calculated using the widely cited method of Biscaye (1965), which uses weighted peak areas to derive a "percentage" of each mineral, without the use of an internal standard. Values calculated for the internal standard method described above were found to correlate significantly with values calculated using Biscaye's method, displaying the same relative trends. However "percentages" of chlorite and kaolinite were found to be consistently higher using the internal standard method relative to the Biscaye method. This study is concerned with trends and relative changes in the clay-mineral abundances, and therefore the same conclusions would be reached using either method. All values cited in this study were calculated using the internal standard method described above.

\section{RESULTS}

\section{Grain Size Distribution}

\section{Site 918}

The lower to middle Eocene deposits of Site 918 analyzed for this study, lithologic Units IV and V, comprise dominantly silt and clay with variable amounts of sand $(0 \%-55 \%)$. The oldest sediment recovered at Site 918 overlies an eroded, subaerially weathered basalt (see Holmes, this volume) and comprises glauconitic clay and silt (lithologic Unit V; Shipboard Scientific Party, 1994a). Interval 152918D-95R-2, 38-40 cm, through 96R-1, 50-52 cm (1181.18-1185.6 mbsf), the base of the glauconitic unit, is rich in sand while the remainder of the sediment in these units has less than $8 \%$ sand (Fig. 2). The sand is predominantly glaucony pellets. Lithologic Unit IV has less glauconite and more volcaniclastic debris with a few coccolithrich laminae. It bears a Mn hardground at the top, in Section 152918D-88R-1. Thin laminae, sparse bioturbation, and a dark color attest to deposition in a sediment-starved, poorly circulating Irminger Basin during the early to middle Eocene.

The Oligocene to lower Miocene deposits consist of lithologic Unit III, a series of very coarse, granule-size, massive conglomerates, highly bioturbated, massive sands, and laminated silts, with fining upward sequences indicative of turbidite deposition (Shipboard Scientific Party, 1994a). These deposits are characterized by their coarse grain size with sand content as high as $87 \%$ near the base of the unit and become finer and more calcareous uphole. Another coarse interval is observed at the top of lithologic Unit III with sand contents of $31 \%-57 \%$. Lithologic Unit II, a clay- and silt-rich glauconitic chalk, is a relatively fine-grained interval consisting predominantly of silt with moderate amounts of clay. Sand content is variable, usually less than $2 \%$, but ranges to as much as $13 \%$ near the top of the unit. The base of lithologic Unit I is dominated by silt with abundant clay and small amounts of sand up to Core 152-918D-24R (504.01 mbsf), above which clay becomes the major constituent. This unit is predominantly hemipelagic mud, with ice-rafted detritus (IRD) first encountered at 543 mbsf in sediment dated as 7 Ma (Larsen et al., 1994). Subtle turbidites dominate the younger part of the section. A large increase in sand is observed in Cores 152-918D-11R and 13R (386.78-404.20 mbsf), where the turbidites are first encountered. Above this interval, several fining-upward sequences are observed with variable amounts of sand, silt, and clay, with silt being the major constituent.

\section{Site 919}

The sediments recovered from Site 919 can be divided into two subunits based on the grain-size data. A relatively fine-grained subunit comprises the upper interval, from 152-919A-1H-1, 1-3 cm, through $10 \mathrm{H}-1,79-81 \mathrm{~cm}(0.01-84.79 \mathrm{mbs})$. A relatively coarser 


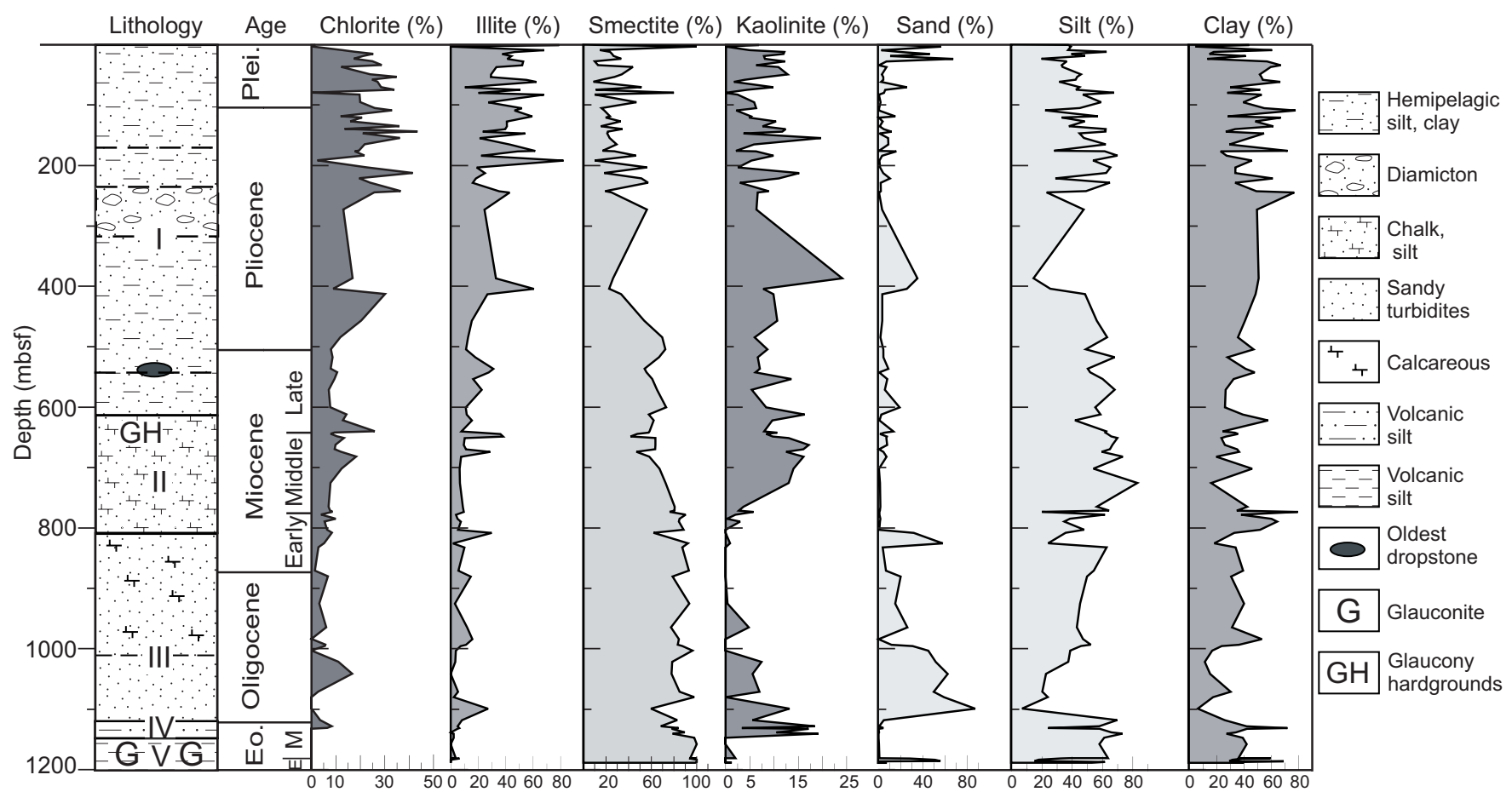

Figure 2. Relative abundance of clay minerals, and sand, silt, and clay percentages of samples collected from ODP Site 918, Irminger Basin. Roman numerals indicate lithologic unit; dashed lines indicate subunits. Eo. = Eocene; Plei. = Pleistocene; E = Early; $\mathrm{M}=$ middle.

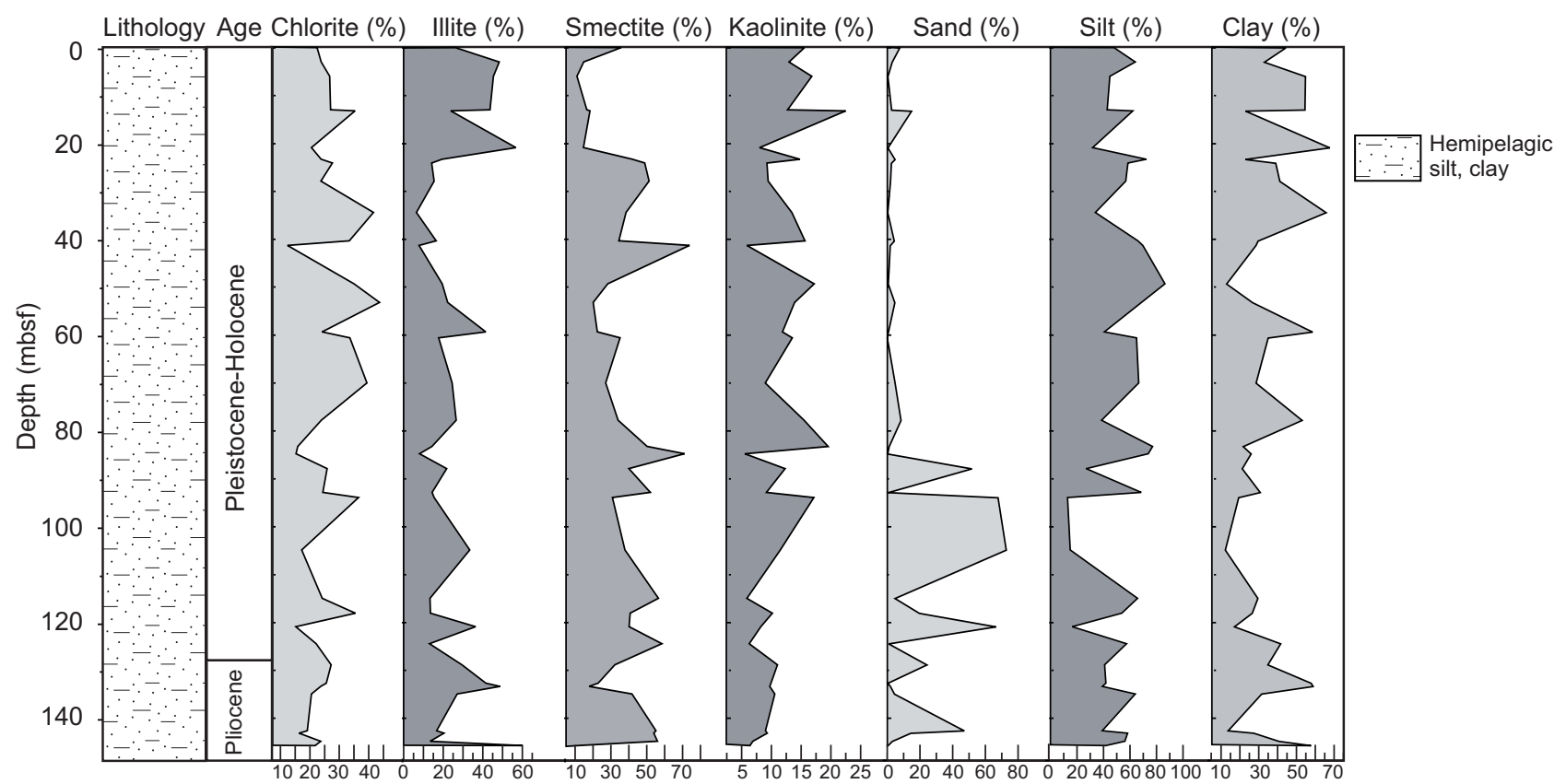

Figure 3. Relative abundance of clay minerals, and sand, silt, and clay percentages of samples collected from ODP Site 919, Irminger Basin.

grained subunit comprises the older interval from 152-919A-10H-3, $83-85 \mathrm{~cm}$, through $8 \mathrm{H}-6,67-69 \mathrm{~cm}$ (Fig. 3). The upper interval is dominated by variable amounts of silt and clay with relatively small amounts of sand (usually $<10 \%$ ). In the lower interval, sand contents vary from $<1 \%$ to $\sim 68 \%$, with varying amounts of silt and clay.

\section{Site 918}

\section{Mineralogy}

The clay minerals at Site 918 consist of smectite, illite, chlorite, kaolinite, and a mixed-layer illite/smectite. Over the entire section at
Site 918, smectite levels are positively correlated, that is, they increase, with depth (Table 1). Chlorite and illite levels increase upsection as smectite levels decline. Illite and smectite are negatively correlated (Table 1).

Lithologic Unit V is dominated by smectite, which averages $98 \%$ and ranges from $94 \%$ to $100 \%$ through this glaucony-rich unit (Fig. 2; Table 2). Chlorite is absent, and illite and kaolinite are present in small amounts, each being in only two samples. Lithologic Unit IV is again dominated by smectite, which averages $84.9 \%$ and ranges from $68 \%$ to $100 \%$. No kaolinite is present in the two samples at the base of Unit IV; however, above the two lowermost samples, levels range 
from $3.4 \%$ to $19.1 \%$, with an average in Unit IV of $9.3 \%$ (Table 2). Illite also becomes more common in Unit IV, ranging from $0 \%$ to $8.2 \%$, with an average of $3.6 \%$. Chlorite makes its first appearance at 1130.86 mbsf (in sediment of middle Eocene age, toward the middle of Unit IV) and is present throughout the remainder of the unit, with levels ranging from $6.4 \%$ to $3.5 \%$ and an average value of $2.3 \%$ (Table 2). Smectite is inversely correlated with illite in this unit as is kaolinite (Table 3 ).

Smectite again dominates the clay-mineral assemblage of the turbidites of lithologic Unit III, but illite and chlorite are more important components, comprising an average of $39.5 \%$ and $4.6 \%$ of the assemblage, respectively (Table 2). Smectite levels are highly variable through this unit, as indicated by their lack of correlation with depth (Table 3). Although grain size and bed thickness decrease uphole through this unit, there is no corresponding change in the mineral composition. Kaolinite levels are relatively high (13.2\%) at the base of this unit, but decline to zero or trace amounts in all but one sample $(152-918 \mathrm{D}-72 \mathrm{R}-1,68-70 \mathrm{~cm})$ in the interval from 1002.75 to 807.74 mbsf, where its abundance increases to $4.8 \%$. Smectite is again inversely correlated with illite within this unit (Table 3 ).

Lithologic Unit II is also dominated by smectite with values ranging from $42 \%$ to $90 \%$ and an average of $67.5 \%$ (Table 2). Chlorite and illite levels increase in this unit with averages of $10.5 \%$ and $12.9 \%$, as do levels of kaolinite, which have an average value of 9.1\%. Smectite levels decrease upsection, whereas, chlorite and kaolinite both increase uphole (Table 3). Illite and kaolinite are both inversely related to smectite in Unit II (Table 3).

Illite becomes the dominant mineral in the clay-mineral assemblage of Unit I with an average value of $37.1 \%$. Levels of all minerals are highly variable in this glacially influenced hemipelagic mud; however, the average value of smectite is considerably lower in this unit (35.4\%; Table 2) than in any of the other units. Kaolinite values range from $0 \%$ to $24 \%$ and have an average of $7.8 \%$ in this unit. Smectite levels again decrease upward in Unit I, while illite levels increase upsection (Table 3 ). Both chlorite and illite are inversely related to smectite in Unit I (Table 3).

R-mode factor analysis was used to identify sample-to-sample relationships at Site 918 . Three factors accounted for $100 \%$ of the total sample-to-sample variance. Factor 1 , which accounts for $65 \%$ of the variance, reflects mostly a dominance of smectite (Fig. 4). This mineral has a high positive scoring coefficient relative to the three other variables, whose coefficients have lower and negative values (Table 4). Factor 2 accounted for $28 \%$ of the variance and has a high positive coefficient for illite and a high negative coefficient for kaolinite (Table 4). Factor 3 accounted for $7 \%$ of the variance and has a high negative coefficient for chlorite and a high positive coefficient for ka-

Table 1. Pearson correlation coefficients for chlorite, smectite, illite, and kaolinite abundance and depth at Site 918.

\begin{tabular}{lrcccc}
\hline & $\begin{array}{r}\text { Depth } \\
(\mathrm{mbsf})\end{array}$ & Chlorite & Smectite & Illite & Kaolinite \\
\hline Depth (mbsf) & 1 & - & - & - & - \\
Chlorite & $\mathbf{- 0 . 7 2 2}$ & 1 & - & - & - \\
Smectite & $\mathbf{0 . 8 5 7}$ & $\mathbf{- 0 . 7 7 5}$ & 1 & - & - \\
Illite & $\mathbf{- 0 . 7 6 3}$ & $\mathbf{0 . 4 7 4}$ & $\mathbf{- 0 . 9 0 1}$ & 1 & 1 \\
Kaolinite & -0.238 & $\mathbf{0 . 3 4 7}$ & $\mathbf{- 0 . 3 9 4}$ & 0.104 & 1 \\
\hline
\end{tabular}

Notes: Significant values are shown in bold type. $\mathrm{C}=0.99$. olinite (Table 4). The factor loadings are plotted by depth in Figure 4. The scoring coefficients for each factor, summarized above, are shown in Table 4.

In addition to the clay minerals, several non-clay minerals were identified in the $<2 \mu \mathrm{m}$ size fraction. These include quartz, amphibole, plagioclase, alkali-feldspar, zeolite, and calcite (Fig. 5). Amphibole is present in lithologic Unit I down to $536 \mathrm{mbsf}$. Quartz and plagioclase are most abundant (as noted by peak intensity) in lithologic Unit I, but quartz is present in trace amounts down to $789 \mathrm{mbsf}$, and plagioclase is present in trace amounts down to $1098.75 \mathrm{mbsf}$ (Fig. 5). Zeolite occurs sporadically in all units except lithologic Unit IV. Calcite is present in most of the samples from Unit II through Unit V, with a noticeable absence between 1117.9 and $993.15 \mathrm{mbsf}$ and in all of lithologic Unit I.

A series of glauconitic hardgrounds occurs at the top of lithologic Unit II (Shipboard Scientific Party, 1994a). Several of these hardgrounds have coarse, sand- to gravel-size, slightly graded, quartzose sediment above them. Where the graded sediments occur, the hardgrounds appear to have been eroded, and rip-up clasts of hardgrounds occur in the overlying sediment. Cycles of hardgrounds with chalk or graded beds overlying the hardgrounds repeat several dozen times through the interval, which is dated as late Miocene age (12 Ma; see Israelson and Spezzaferri, this volume). Above this interval of hardground-graded bed couplets lies lithologic Unit I, which contains no calcareous microfossils. Nondeposition, as indicated by the hardgrounds, the presence of graded coarse beds, and the subsequent absence of calcareous sediment, suggests that this interval formed dur-

Table 3. Pearson correlation coefficients for chlorite, smectite, illite, and kaolinite abundance and depth at Site 918 for lithologic Units I-V.

\begin{tabular}{|c|c|c|c|c|c|}
\hline & $\begin{array}{l}\text { Depth } \\
\text { (mbsf) }\end{array}$ & Chlorite & Smectite & Illite & Kaolinite \\
\hline \multicolumn{6}{|l|}{ Unit I } \\
\hline Depth (mbsf) & 1 & - & - & - & - \\
\hline Chlorite & -0.314 & 1 & - & - & - \\
\hline Smectite & 0.515 & -0.536 & 1 & - & - \\
\hline Illite & -0.452 & -0.001 & -0.821 & 1 & - \\
\hline Kaolinite & 0.152 & 0.255 & -0.126 & -0.235 & 1 \\
\hline \multicolumn{6}{|l|}{ Unit II } \\
\hline Depth (mbsf) & 1 & - & - & - & - \\
\hline Chlorite & -0.594 & 1 & - & - & - \\
\hline Smectite & 0.877 & -0.508 & 1 & - & - \\
\hline Illite & -0.522 & -0.012 & -0.782 & 1 & - \\
\hline Kaolinite & -0.764 & 0.438 & -0.686 & 0.196 & 1 \\
\hline \multicolumn{6}{|l|}{ Unit III } \\
\hline Depth (mbsf) & 1 & - & - & - & - \\
\hline Chlorite & -0.077 & 1 & - & - & - \\
\hline Smectite & -0.048 & -0.352 & 1 & - & - \\
\hline Illite & -0.166 & -0.149 & -0.807 & 1 & - \\
\hline Kaolinite & 0.588 & 0.161 & -0.588 & 0.202 & 1 \\
\hline \multicolumn{6}{|l|}{ Unit IV } \\
\hline Depth (mbsf) & 1 & - & - & - & - \\
\hline Chlorite & -0.591 & 1 & - & - & - \\
\hline Smectite & 0.728 & -0.599 & 1 & - & - \\
\hline Illite & -0.865 & 0.643 & -0.567 & 1 & - \\
\hline Kaolinite & -0.354 & 0.128 & -0.842 & 0.106 & 1 \\
\hline \multicolumn{6}{|l|}{ Unit V } \\
\hline Depth (mbsf) & 1 & - & - & - & - \\
\hline Chlorite & - & - & - & - & - \\
\hline Smectite & 0.554 & - & 1 & - & - \\
\hline Illite & -0.595 & - & -0.959 & 1 & - \\
\hline Kaolinite & -0.091 & - & -0.51 & 0.245 & 1 \\
\hline
\end{tabular}

Notes: Significant values are shown in bold type. $\mathrm{C}=0.99$.

Table 2. Average abundance values and standard deviations of clay minerals in lithologic Units I-V at Site 918.

\begin{tabular}{|c|c|c|c|c|c|c|c|c|}
\hline \multirow{2}{*}{$\begin{array}{c}\text { Lithologic } \\
\text { unit }\end{array}$} & \multicolumn{2}{|c|}{ Chlorite } & \multicolumn{2}{|c|}{ Smectite } & \multicolumn{2}{|c|}{ Illite } & \multicolumn{2}{|c|}{ Kaolinite } \\
\hline & Average & Std. dev. & Average & Std. dev. & Average & Std. dev. & Average & Std. dev. \\
\hline I & 19.7 & 10.5 & 35.4 & 21.8 & 37.1 & 19.0 & 7.8 & 4.5 \\
\hline II & 10.5 & 4.8 & 67.5 & 14.0 & 12.9 & 9.9 & 9.1 & 5.5 \\
\hline III & 4.7 & 4.6 & 83.3 & 11.0 & 9.5 & 8.8 & 2.5 & 4.0 \\
\hline IV & 2.3 & 3.4 & 84.9 & 10.6 & 3.6 & 3.0 & 9.3 & 8.2 \\
\hline V & 0.0 & 0.0 & 98.3 & 2.7 & 1.3 & 2.4 & 0.4 & 0.8 \\
\hline
\end{tabular}




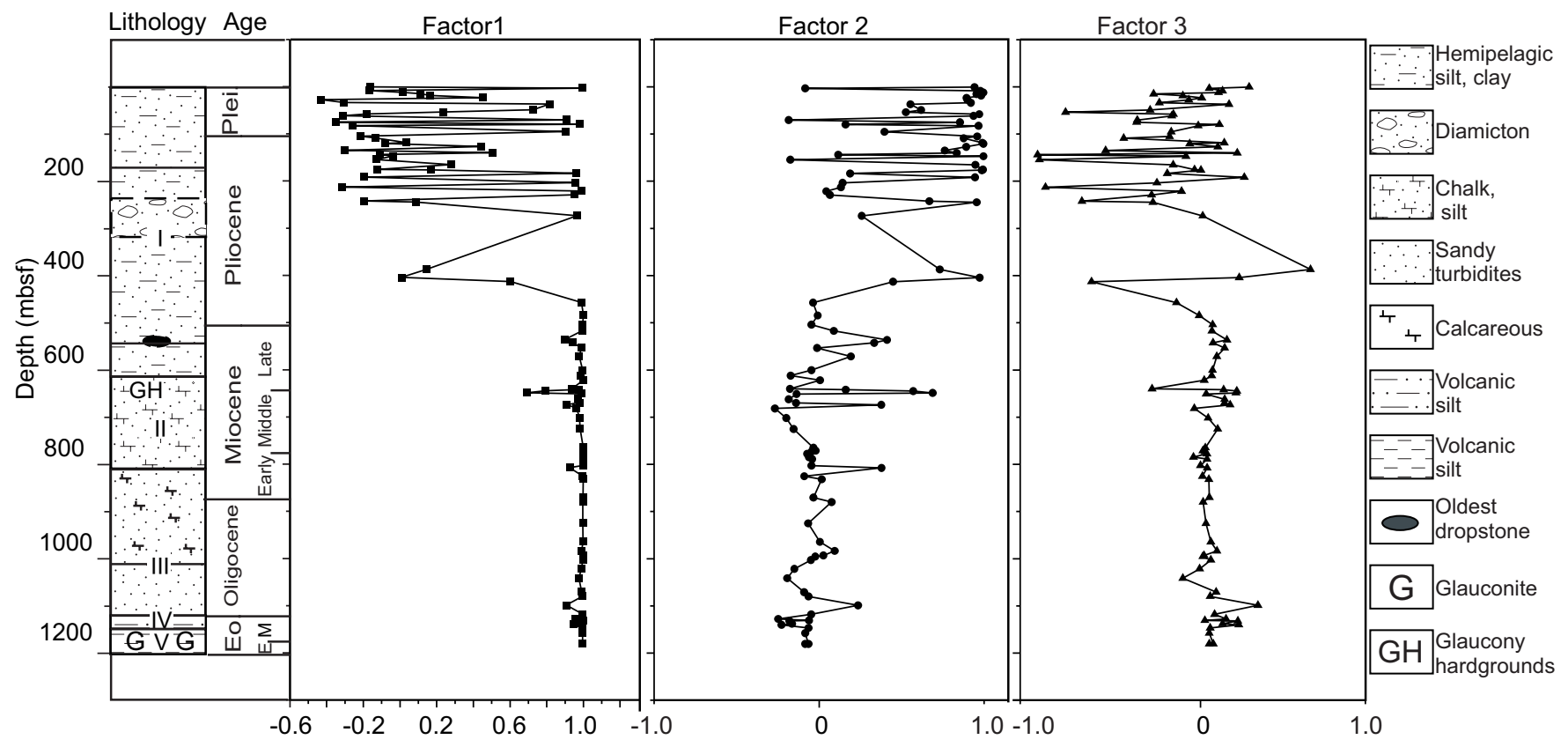

Figure 4. Loadings of the three factors identified for Site 918 plotted by depth. A dramatic change in the values of all three factors is noticeable at 457 mbsf, which is interpreted to be signaling major continental glaciation on Greenland. For key to lithology and age symbols, see Figure 2.

Table 4. Scoring coefficients for the results of an R-mode factor analysis of the Site 918 clay mineral abundance data.

\begin{tabular}{lccc}
\hline & Factor 1 & Factor 2 & Factor 3 \\
\hline Chlorite & -0.456 & -0.33 & -1.39 \\
Smectite & 1.492 & -0.128 & 0.08 \\
Illite & -0.4 & 1.406 & 0.337 \\
Kaolinite & -0.636 & -0.948 & 0.973 \\
\hline
\end{tabular}

ing the spillover of Arctic water into this region (Shipboard Scientific Party, 1994a). We had hoped to pick enough hardground material to date it using K-Ar. X-ray results, however, indicate the ubiquitous presence of detrital mica, and we were unable to physically segregate the detrital from the authigenic mineral. The authigenic mineral is a highly expandable mixed-layer 10/17 A mineral. Sediments immediately above and from within the hardgrounds were compared and revealed a similar detrital paragenesis: kaolinite, quartz, plagioclase, potassium feldspar, mica, and a trace of amphibole. Calcite is also present as microfossils. A zeolite, probably clinoptilolite, is sporadically present. The sediment above the hardgrounds also contains an expandable 10/17 A mineral, but this peak tends to be less sharp than that from the hardground. The only mineral present in the hardgrounds and not observed in the surrounding sediment is diagenetic quartz, indicated by the greater intensity of the $4.26 \AA$ peak relative to the $3.34 \AA$ A peak (Eslinger et al., 1973).

\section{Site 919}

The clay-mineral assemblage at Site 919 is similar to the assemblage in the coeval section of Site 918 (lithologic Unit I). Smectite, illite, kaolinite, and chlorite are the clay minerals present, and the relative abundances of each are somewhat variable downhole. Overall, illite is less common (relative to the other clay minerals) at Site 919 than in the Pliocene-Pleistocene sediments from Site 918 (Figs. 2, 3). A noticeable increase in illite and a corresponding decrease in smectite are apparent near the top of the hole at about $20 \mathrm{mbsf}$, but variations in mineral content with depth are not statistically significant (Table 5). Kaolinite abundance decreases downhole (Table 5), while chlorite content remains fairly consistent. Illite and smectite levels are inversely correlated, as are chlorite and smectite, and kaolinite and smectite levels (Table 5). Several non-clay minerals occur in the sediment at Site 919. They include quartz, amphibole, plagioclase, pyroxene, alkali-feldspar, zeolites, and calcite (Fig. 6).

\section{DISCUSSION}

The increase of smectite level with depth at both Sites 918 and 919 suggests that this sediment has not been subjected to extensive burial diagenesis. Diagenesis induced by elevated temperatures would have altered smectite to illite, resulting in a decrease in smectite content with depth, and an increase in illite content with depth.

\section{Site 918}

\section{Early Eocene to Middle Eocene}

Shipboard observation revealed the presence of up to $70 \%$ glauconite pellets in lithologic Unit V from Site 918 (Shipboard Scientific Party, 1994a). The clay-mineral assemblage of this unit is almost entirely composed of smectite, with some kaolinite near the base of the unit and illite occurring in two samples near the top. The glauconite pellets are therefore believed to be composed of smectite that formed authigenically from the alteration of a detrital mineral.

Kaolinite is considered to be a "low latitude" mineral, a product of chemical weathering (Chamley, 1989). It is considered a secondary mineral that forms from the subaerial alteration of some parent mineral (e.g., feldspar) during soil forming processes and indicates intense chemical weathering typical in low latitude, tropical to subtropical areas. However, care must be taken when using kaolinite as an indicator of climatic conditions, because it is essentially an endproduct of chemical weathering and may be reworked or "recycled" from pre-existing deposits, thus lending no information about the climatic conditions at the time of deposition (Naidu et al., 1971; Darby, 1975; Krissek, 1989). The Eocene is widely accepted as being a very warm period in the Earth's history. Eocene floras from the Gulf of Alaska $\left(60^{\circ}-61^{\circ} \mathrm{N}\right.$ latitude) typify a paratropical rain forest and indicate the warmest Tertiary climate for Alaska (Wolfe, 1978). The ka- 


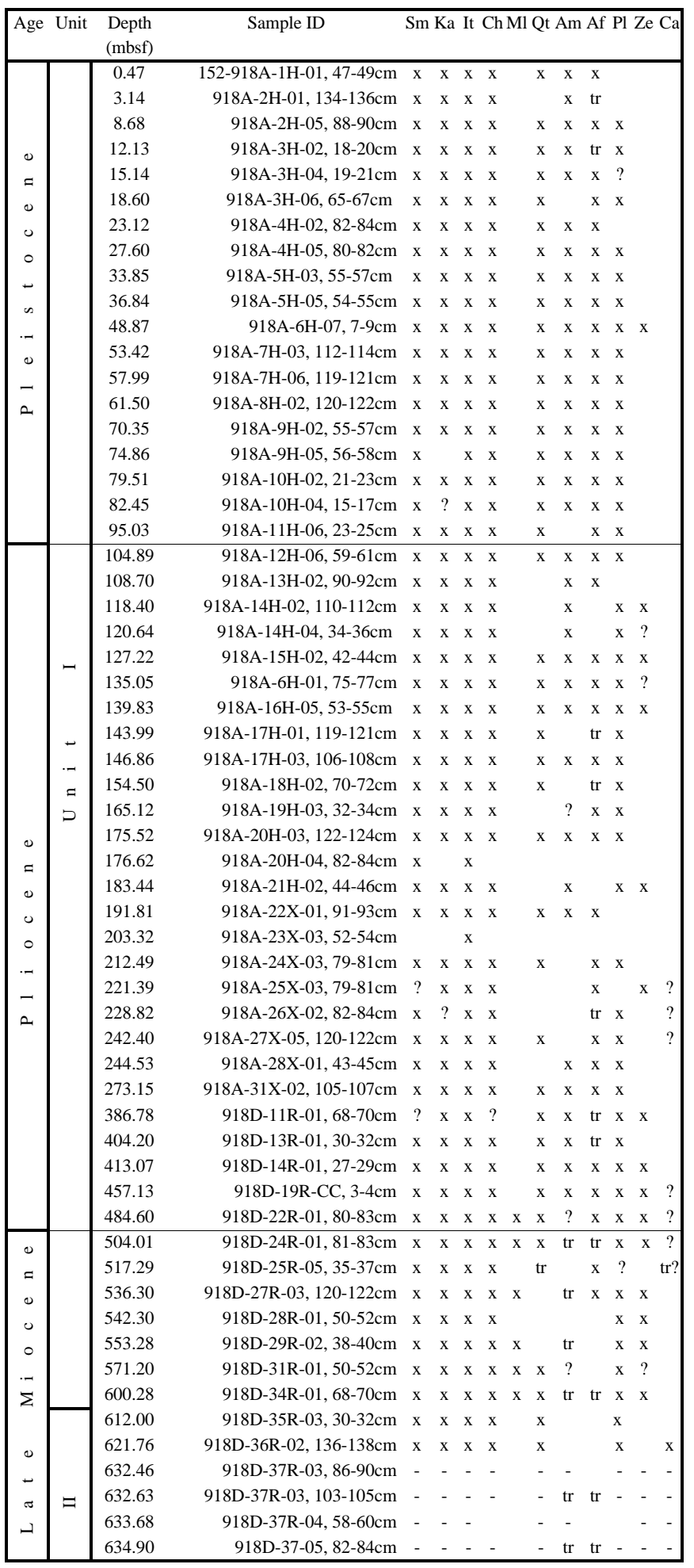

\begin{tabular}{|c|c|c|c|c|c|c|c|c|c|c|c|c|c|}
\hline$\overline{\text { Age }}$ & Unit & $\begin{array}{l}\text { Depth } \\
\text { (mbsf) }\end{array}$ & Sample ID & $\mathrm{Sm}$ & $\overline{\mathrm{Ka}}$ & It $C$ & & $\overline{\mathrm{Ml}}$ & $\overline{\text { Qt A }}$ & $\mathrm{Am}$ & $\mathrm{fPl}$ & $\overline{\mathrm{Ze}}$ & $\mathrm{Ca}$ \\
\hline () & & & & & & & & & & & & & \\
\hline$=$ & & 641.84 & 152-918D-38R-03, 64-67cm & $\mathrm{x}$ & $\mathrm{x}$ & $\mathrm{x}$ & $\mathrm{x}$ & & $\mathrm{x}$ & & $\operatorname{tr}$ & $\mathrm{x}$ & $\mathrm{x}$ \\
\hline 0 & & 644.53 & 918D-38R-05,. 33-35cm & $\mathrm{x}$ & $\mathrm{x}$ & $\mathrm{x}$ & $\operatorname{tr}$ & & $\mathrm{x}$ & & $\operatorname{tr}$ & $\mathrm{x}$ & $\mathrm{x}$ \\
\hline 0 & & 648.64 & 918D-39R-01, 74-76cm & $\mathrm{x}$ & $\mathrm{x}$ & $\mathrm{x}$ & $?$ & & $\operatorname{tr}$ & & $\operatorname{tr}$ & $\mathrm{x}$ & $\mathrm{x}$ \\
\hline 0 & & 651.03 & 918D-39R-03, 13-15cm & $\mathrm{x}$ & $\mathrm{x}$ & $\mathrm{x}$ & & & $\operatorname{tr}$ & & $\operatorname{tr}$ & & $\mathrm{x}$ \\
\hline & & 662.30 & 918D-40R-04, 30-32cm & $\mathrm{x}$ & $?$ & $\mathrm{x}$ & $\mathrm{x}$ & & $\operatorname{tr}$ & & & & $\mathrm{x}$ \\
\hline$\Sigma$ & $=$ & 669.83 & 918D-41R-02, 113-115cm & $\mathrm{x}$ & $\mathrm{x}$ & $\mathrm{x}$ & $\mathrm{x}$ & & $\mathrm{x}$ & & $\mathrm{x}$ & & $\mathrm{x}$ \\
\hline & & 674.07 & 918D-41R-05, 87-89cm & $\mathrm{x}$ & $\mathrm{x}$ & $\mathrm{x}$ & $\operatorname{tr}$ & $\mathrm{x}$ & $\operatorname{tr}$ & & $\mathrm{x}$ & & $\mathrm{x}$ \\
\hline$\tau$ & - & 681.84 & $918 \mathrm{D}-42 \mathrm{R}-04,54-56 \mathrm{~cm}$ & $\mathrm{x}$ & $\mathrm{x}$ & $\mathrm{x}$ & $\mathrm{x}$ & $\mathrm{x}$ & & & $\mathrm{x}$ & & $\mathrm{x}$ \\
\hline. &. & 701.94 & 918D-44R-04, 134-137cm & $\mathrm{x}$ & $\mathrm{x}$ & $\mathrm{x}$ & $\mathrm{x}$ & $\mathrm{x}$ & $\operatorname{tr}$ & & $\mathrm{x}$ & & $\mathrm{x}$ \\
\hline$\Sigma$ & $=$ & 725.33 & $918 \mathrm{D}-47 \mathrm{R}-02,13-15 \mathrm{~cm}$ & $\mathrm{x}$ & $\mathrm{x}$ & $\mathrm{x}$ & $\mathrm{x}$ & & $\operatorname{tr}$ & & $\operatorname{tr}$ & & $\mathrm{x}$ \\
\hline & D & 764.70 & 918D-51R-02, 0-5cm & $\mathrm{x}$ & $?$ & $\mathrm{x}$ & $\mathrm{x}$ & $\mathrm{x}$ & $\operatorname{tr}$ & & & $\mathrm{x}$ & $\bar{x}$ \\
\hline 0 & & 771.15 & 918D-51R-06, 45-48cm & $\mathrm{x}$ & $\mathrm{x}$ & $\mathrm{x}$ & & $\mathrm{x}$ & $\operatorname{tr}$ & & & $\mathrm{x}$ & \\
\hline$=$ & & 773.24 & 918D-52R-01, 34-36cm & $\mathrm{x}$ & & $\mathrm{x}$ & $\operatorname{tr}$ & $\mathrm{x}$ & & & & $\mathrm{x}$ & $\mathrm{x}$ \\
\hline () & & 777.91 & 918D-52R-04, 51-53cm & $\mathrm{x}$ & & $\mathrm{x}$ & $\operatorname{tr}$ & $\mathrm{x}$ & & & & $\mathrm{x}$ & $\mathrm{x}$ \\
\hline u & & 784.58 & 918D-53R-02, 58-60cm & $\mathrm{x}$ & $\mathrm{x}$ & $\mathrm{x}$ & & $\mathrm{x}$ & & & & $\mathrm{x}$ & $\mathrm{x}$ \\
\hline 0 & & 789.18 & 918D-53R-05, 68-70cm & $\mathrm{x}$ & $\mathrm{x}$ & $\mathrm{x}$ & $\operatorname{tr}$ & $\mathrm{x}$ & $\operatorname{tr}$ & & & $\mathrm{x}$ & $\mathrm{x}$ \\
\hline . & & 802.59 & 918D-55R-01, 79-81cm & $\mathrm{x}$ & $\mathrm{x}$ & $\mathrm{x}$ & & $\mathrm{x}$ & & & & $\mathrm{x}$ & $\mathrm{x}$ \\
\hline$\Sigma$ & & 807.74 & 918D-55R- 05, 22-25cm & $\mathrm{x}$ & $\mathrm{x}$ & $\mathrm{x}$ & & $\mathrm{x}$ & & & & $\mathrm{x}$ & \\
\hline & & 825.18 & 918D-57R-03, 118-120cm & $\mathrm{x}$ & $\mathrm{x}$ & $\mathrm{x}$ & & $\mathrm{x}$ & & & $\operatorname{tr}$ & $\mathrm{x}$ & $\mathrm{x}$ \\
\hline 工्د & & 831.74 & 918D-58R- 01, 104-106cm & $\mathrm{x}$ & $\mathrm{x}$ & $\mathrm{x}$ & & $\mathrm{x}$ & & & $\mathrm{x}$ & $\mathrm{x}$ & $\mathrm{x}$ \\
\hline & & 870.46 & 918D-62R-01, 116-118cm & $\mathrm{x}$ & $\mathrm{x}$ & & & $\mathrm{x}$ & & & & & $\mathrm{x}$ \\
\hline & & 879.93 & 918D-63R-01, 103-106cm & $\mathrm{x}$ & & $\mathrm{x}$ & $\mathrm{x}$ & $\mathrm{x}$ & & & & & $\mathrm{x}$ \\
\hline () & & 925.02 & 918D-68R-01, 2-5cm & $\mathrm{x}$ & $\mathrm{x}$ & & & $\mathrm{x}$ & & & & & \\
\hline$=$ & $\Xi$ & 964.38 & $918 \mathrm{D}-72 \mathrm{R}-01,68-70 \mathrm{~cm}$ & $\mathrm{x}$ & & $\operatorname{tr}$ & $\operatorname{tr}$ & $\mathrm{x}$ & & & & & \\
\hline ه & ـ & 983.54 & 918D-74R-01, 84-86cm & $\mathrm{x}$ & & $\operatorname{tr}$ & & $\mathrm{x}$ & & & & & $\mathrm{x}$ \\
\hline 0 & - & 993.15 & 918D-75R-01, 85-87cm & $\mathrm{x}$ & $\mathrm{x}$ & $\mathrm{x}$ & & $\mathrm{x}$ & & & & & \\
\hline 0 & $=$ & 995.31 & 918D-75R-03, 1-3cm & $\mathrm{x}$ & $?$ & $?$ & $\mathrm{x}$ & $\mathrm{x}$ & & & & & \\
\hline os & $\triangleright$ & 1002.75 & 918D-76R-01, 75-77cm & $\mathrm{x}$ & $\mathrm{x}$ & $\operatorname{tr}$ & $\mathrm{x}$ & & $\operatorname{tr}$ & $r ?$ & $\operatorname{tr}$ & & \\
\hline & & 1021.38 & 918D-78R-01, 18-21cm & $\mathrm{x}$ & $\mathrm{x}$ & $\operatorname{tr}$ & $\mathrm{x}$ & $\mathrm{x}$ & & & & & \\
\hline- & & 1041.22 & 918D-80R-01, 62-64cm & $\mathrm{x}$ & $\operatorname{tr}$ & $\mathrm{x}$ & $\mathrm{x}$ & $?$ & & & $\operatorname{tr}$ & & \\
\hline 0 & & 1070.94 & 918D-83R-01, 134-137cm & $\mathrm{x}$ & $\mathrm{x}$ & $\operatorname{tr}$ & & $\mathrm{x}$ & & & $\operatorname{tr}$ & & \\
\hline & & 1079.83 & 918D-84R-01, 52-55cm & $\mathrm{x}$ & & $\operatorname{tr}$ & $?$ & $\mathrm{x}$ & & & $\operatorname{tr}$ & & \\
\hline & & 1098.75 & 918D-86R-01, 25-27cm & $\mathrm{x}$ & $\mathrm{x}$ & $\mathrm{x}$ & $\mathrm{x}$ & & & & $\operatorname{tr}$ & & \\
\hline () & & 1117.90 & 918D-88R-01, 10-12cm & $\mathrm{x}$ & $\mathrm{x}$ & $\mathrm{x}$ & & $\mathrm{x}$ & & & & & \\
\hline$=$ & $\geq$ & 1127.74 & $918 \mathrm{D}-89 \mathrm{R}-01,34-35 \mathrm{~cm}$ & $\mathrm{x}$ & $\mathrm{x}$ & $\operatorname{tr}$ & & $\mathrm{x}$ & & & & & $\mathrm{x}$ \\
\hline 0 & & 1130.86 & $918 \mathrm{D}-89 \mathrm{R}-03,46-48 \mathrm{~cm}$ & $\mathrm{x}$ & $\operatorname{tr}$ & $\operatorname{tr}$ & & $\mathrm{x}$ & & & & & $\mathrm{x}$ \\
\hline 0 & - & 1132.02 & $918 \mathrm{D}-89 \mathrm{R}-04,62-64 \mathrm{~cm}$ & $\mathrm{x}$ & $\mathrm{x}$ & $\mathrm{x}$ & & $\mathrm{x}$ & & & & & $\mathrm{x}$ \\
\hline 0 &.- & 1137.97 & $918 \mathrm{D}-90 \mathrm{R}-02,53-55 \mathrm{~cm}$ & $\mathrm{x}$ & $\mathrm{x}$ & $?$ & & $?$ & & & & & $\mathrm{x}$ \\
\hline$山$ & $=$ & 1140.06 & 918D-90R-03, 112-114cm & $\mathrm{x}$ & $\mathrm{x}$ & $?$ & & $\mathrm{x}$ & & & & & $\mathrm{x}$ \\
\hline & $\triangleright$ & 1146.67 & 918D-91R-01, 17-19cm & $\mathrm{x}$ & $\mathrm{x}$ & & & & & & & & $\mathrm{x}$ \\
\hline$\sum$ & & 1157.74 & 918D-92R-02, 44-46cm & $\mathrm{x}$ & & & & $?$ & & & & $\mathrm{x}$ & $\mathrm{x}$ \\
\hline & & 1180.48 & 918D-95R-01, 08-09cm & $\mathrm{x}$ & $\mathrm{x}$ & $\mathrm{x}$ & & $\mathrm{x}$ & & & & $\mathrm{x}$ & $\mathrm{x}$ \\
\hline & $>$ & 1180.57 & 918D-95R-01, 17-18cm & $\mathrm{x}$ & & & & & & & & $\mathrm{x}$ & $\mathrm{x}$ \\
\hline & & 1181.18 & 918D-95R-02, 38-40cm & $\mathrm{x}$ & & $\mathrm{x}$ & & $\mathrm{x}$ & $\mathrm{x}$ & $\mathrm{x}$ & $\mathrm{x}$ & $\mathrm{x}$ & $\mathrm{x}$ \\
\hline & & 1183.32 & 918D-95R-03, 102-104cm & $\mathrm{x}$ & & & & & & & & $\mathrm{x}$ & \\
\hline & .7 & 1185.60 & 918D-96R-01, 50-52cm & $\mathrm{x}$ & & & & $\mathrm{x}$ & & & & $\mathrm{x}$ & \\
\hline If & $=$ & 1185.76 & 918D-96R-02, 04-05cm & $\mathrm{x}$ & & & & $\mathrm{x}$ & & & & $\mathrm{x}$ & ? \\
\hline & $\triangleright$ & 1186.96 & 918D-96R- 02, 124-126cm & $\mathrm{x}$ & & & & $\mathrm{x}$ & & & & & \\
\hline 디 & & 1188.45 & 918D-96R-03, 123-125cm & $\mathrm{x}$ & $\mathrm{x}$ & & & $\mathrm{x}$ & & & & & \\
\hline
\end{tabular}

Figure 5. Mineral composition of sediments from Site 919. $\mathrm{Sm}=$ smectite, $\mathrm{Ka}=$ kaolinite, $\mathrm{It}=\mathrm{illite}, \mathrm{Ch}=\mathrm{chlorite}, \mathrm{Ml}=\mathrm{mixed}-\mathrm{layer}$ illite/smectite, $\mathrm{Qt}=\mathrm{quartz}$, $\mathrm{Am}=$ amphibole, $\mathrm{Af}=$ alkali feldspar, $\mathrm{Pl}=$ plagioclase, $\mathrm{Ze}=$ zeolite, $\mathrm{Ca}=$ calcite, $\mathrm{X}=$ present, $\mathrm{tr}=$ present in trace amount.

olinite found in the Eocene sediments from Site 918 may reflect similar warm climatic conditions. Holmes (this volume) found kaolinite and gibbsite present in the subaerially weathered basalt at Site 918 and at Sites 915 and 916 on the adjacent Greenland shelf. The absence of chlorite further indicates a warm climate.

Chlorite is generally considered to be associated with high latitudes and physical weathering. It cannot easily persist in areas of in- tense chemical weathering because it is easily eliminated by hydrolysis (Biscaye, 1965). Illite is also readily affected by hydrolysis (Singer, 1984), and its near absence in the Eocene may be due to conditions similar to those previously discussed for chlorite. The appearance of illite in lower Eocene sediment (Sample 152-918D-95R-2, $38-40 \mathrm{~cm}$ ) coincides with a change in sediment chemistry, indicating that in the early Eocene more felsic source areas became exposed and 
Table 5. Pearson correlation coefficients for chlorite, smectite, illite, and kaolinite abundance and depth at Site 919.

\begin{tabular}{lrcccc}
\hline & $\begin{array}{c}\text { Depth } \\
(\mathrm{mbsf})\end{array}$ & Chlorite & Smectite & Illite & Kaolinite \\
\hline Depth (mbsf) & 1 & - & - & - & - \\
Chlorite & -0.268 & 1 & - & - & - \\
Smectite & 0.379 & $-\mathbf{0 . 4 8 2}$ & 1 & - & - \\
Illite & -0.161 & -0.135 & $\mathbf{- 0 . 7 7 4}$ & 1 & 1 \\
Kaolinite & $\mathbf{- 0 . 4 6 6}$ & 0.427 & $\mathbf{- 0 . 5 3 1}$ & 0.089 & 1 \\
\hline
\end{tabular}

Notes: Significant values are shown in bold type. $\mathrm{C}=0.99$.

\begin{tabular}{|c|c|c|c|c|c|c|c|c|c|c|c|c|c|}
\hline Age & $\begin{array}{l}\text { Depth } \\
\text { (mbsf) }\end{array}$ & Sample & Sm & $\mathrm{Ka}$ & It & $\mathrm{Ch}$ & Qt & $\mathrm{Am}$ & $\mathrm{PI}$ & Af & $\mathrm{Ze}$ & $\mathrm{Ca}$ & Py \\
\hline \multirow{11}{*}{$\begin{array}{c}0 \\
\subset \\
0 \\
0 \\
0 \\
- \\
0 \\
I\end{array}$} & 0.01 & 152-919A-1H-1, 1-3 & $\bar{x}$ & $\mathrm{x}$ & $\mathrm{x}$ & $\bar{x}$ & $\mathrm{x}$ & $\mathrm{x}$ & $\mathrm{x}$ & $\operatorname{tr}$ & $\mathrm{x}$ & $\bar{x}$ & \\
\hline & 3.01 & 919A-1H-3, 1-3 & $\mathrm{x}$ & $\mathrm{x}$ & $\mathrm{x}$ & $\mathrm{x}$ & $\mathrm{x}$ & $\mathrm{x}$ & $\mathrm{x}$ & $\mathrm{x}$ & $\mathrm{x}$ & $\mathrm{x}$ & \\
\hline & 6.01 & $919 \mathrm{~A}-1 \mathrm{H}-5,1-3$ & $x$ & $x$ & $x$ & $x$ & $x$ & $x$ & $x$ & $x$ & $x$ & & \\
\hline & 12.98 & $919 \mathrm{~A}-2 \mathrm{H}-4,48-50$ & $x$ & $x$ & $x$ & $x$ & $x$ & $x$ & $x$ & $x$ & $x$ & & \\
\hline & 13.19 & $919 \mathrm{~A}-2 \mathrm{H}-4,69-71$ & $\mathrm{x}$ & $\mathrm{x}$ & $x$ & $\mathrm{x}$ & $\mathrm{x}$ & & $\mathrm{x}$ & $\mathrm{x}$ & \multicolumn{3}{|c|}{$\mathrm{x}$} \\
\hline & 20.84 & 919A-3H-3, 34-36 & $\mathrm{x}$ & $\mathrm{x}$ & $x$ & $\mathrm{x}$ & $x$ & $\mathrm{x}$ & $\mathrm{x}$ & $\mathrm{x}$ & & & \\
\hline & 23.3 & $919 \mathrm{~A}-3 \mathrm{H}-4,130-132$ & $\mathrm{x}$ & $\mathrm{x}$ & $\mathrm{x}$ & $\mathrm{x}$ & $\mathrm{x}$ & $\mathrm{x}$ & $\mathrm{x}$ & $\mathrm{x}$ & $\mathrm{x}$ & & \\
\hline & 24.1 & $919 \mathrm{~A}-3 \mathrm{H}-, 5,60-62$ & $x$ & $x$ & $x$ & $x$ & $x$ & $x$ & $x$ & $x$ & $x$ & $x$ & \\
\hline & 27.85 & $919 \mathrm{~A}-4 \mathrm{H}-1,85-87$ & $\mathrm{x}$ & $\mathrm{x}$ & $\mathrm{x}$ & $\mathrm{x}$ & $\mathrm{x}$ & $\mathrm{x}$ & $\mathrm{x}$ & $\mathrm{x}$ & $\mathrm{x}$ & $\mathrm{x}$ & $\mathrm{x}$ \\
\hline & 34.39 & $919 \mathrm{~A}-4 \mathrm{H}-5,139-141$ & $x$ & $x$ & $x$ & $x$ & $x$ & $x$ & $x$ & $\mathrm{x}$ & $x$ & & $\operatorname{tr}$ \\
\hline & 40.32 & 919A-5H-3, 82-84 & $x$ & $x$ & $x$ & $x$ & & & $x$ & $x$ & $x$ & $x$ & \\
\hline & .29 & 919 & $x$ & $x$ & $x$ & $x$ & $\operatorname{tr}$ & $\operatorname{tr}$ & $x$ & $x$ & $x$ & $x$ & $\mathrm{x}$ \\
\hline & .33 & 3-35 & $x$ & $x$ & $x$ & $x$ & $x$ & $\operatorname{tr}$ & $x$ & $x$ & $x$ & $x$ & $x$ \\
\hline & 3.17 & $919 A-6 \mathrm{H}$ & $x$ & $x$ & $x$ & $x$ & $x$ & $x$ & $x$ & $x$ & $x$ & & \\
\hline & 59.33 & 3, 83-85 & $x$ & $x$ & $x$ & $x$ & $x$ & $x$ & $x$ & $x$ & $x$ & $x$ & \\
\hline 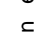 & 60.59 & 4, 59-61 & $x$ & $x$ & $x$ & $x$ & $x$ & $x$ & $x$ & $x$ & & $x$ & $\mathrm{x}$ \\
\hline 0 & 70.01 & $919 \mathrm{~A}-8 \mathrm{H}-$ & $x$ & $x$ & $x$ & $x$ & $x$ & $x$ & $x$ & $x$ & $\mathrm{x}$ & $x$ & $x$ \\
\hline & 77.74 & 919A & $\mathrm{x}$ & $x$ & $x$ & $x$ & $x$ & $x$ & $x$ & $x$ & & $x$ & \\
\hline 0 & 83.23 & 919A-9ト & $x$ & $x$ & $x$ & $x$ & $x$ & $\operatorname{tr}$ & $x$ & $x$ & $\mathrm{x}$ & $x$ & \\
\hline 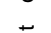 & 84.79 & 79-81 & $x$ & $x$ & $x$ & $x$ & tr & tr & $x$ & $x$ & $x$ & $x$ & $\mathrm{x}$ \\
\hline$\infty$ & 87.83 & $3-85$ & $\mathrm{x}$ & $\mathrm{x}$ & $x$ & $\mathrm{x}$ & $\mathrm{x}$ & $\mathrm{x}$ & $\mathrm{x}$ & $\mathrm{x}$ & & & $\mathrm{x}$ \\
\hline & 92.82 & 919B-3 & $x$ & $x$ & $x$ & $x$ & tr & tr & $x$ & & & $\mathrm{x}$ & \\
\hline 0 & 93.89 & $-3,89-91$ & $x$ & $x$ & $x$ & $x$ & $x$ & & $x$ & $\mathrm{x}$ & $\mathrm{x}$ & $x$ & \\
\hline & 104.86 & $6-88$ & $\mathrm{x}$ & $\mathrm{x}$ & $\mathrm{x}$ & $\mathrm{x}$ & $\mathrm{x}$ & $x$ & & $\mathrm{x}$ & $\mathrm{x}$ & $\mathrm{x}$ & \\
\hline & 4.95 & 919B-5 & $\mathrm{x}$ & $\mathrm{x}$ & $\mathrm{x}$ & $\mathrm{x}$ & $\mathrm{x}$ & $\mathrm{x}$ & $\mathrm{x}$ & $\mathrm{x}$ & $\mathrm{x}$ & $\mathrm{x}$ & $\mathrm{x}$ \\
\hline & 8.04 & , $2-4$ & $x$ & $x$ & $x$ & $x$ & $x$ & $x$ & $x$ & $x$ & $x$ & & \\
\hline & 120.83 & $83-85$ & $x$ & $x$ & $x$ & $x$ & tr & tr & & $x$ & & $x$ & \\
\hline & 24.4 & 919B-6H-4, 140-142 & $x$ & $x$ & $x$ & $x$ & & $x$ & $x$ & $x$ & $\mathrm{x}$ & & \\
\hline & 128.83 & 919B-7H-1, 83-85 & $\mathrm{x}$ & $\mathrm{x}$ & $x$ & $x$ & $\mathrm{x}$ & $\operatorname{tr}$ & $x$ & $\mathrm{x}$ & $x$ & & \\
\hline & 132.62 & $2-14$ & $x$ & $x$ & $x$ & $x$ & $x$ & $x$ & $x$ & $x$ & $x$ & & \\
\hline . & 33.3 & $80-82$ & $x$ & $x$ & $x$ & $x$ & $x$ & $x$ & $x$ & $x$ & $x$ & & \\
\hline 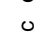 & 134.89 & 5, 89-91 & $\mathrm{x}$ & $\mathrm{x}$ & $\mathrm{x}$ & $x$ & $\mathrm{x}$ & $x$ & $x$ & $\mathrm{x}$ & $x$ & & \\
\hline . & 142.57 & 919B-8H-4, 57-59 & $x$ & $x$ & $x$ & $x$ & $\mathrm{x}$ & $x$ & $x$ & $x$ & $x$ & & $\mathrm{x}$ \\
\hline & 143.03 & 919B-8H-4, 103-105 & $x$ & $x$ & $x$ & $x$ & $x$ & $x$ & $x$ & $x$ & $x$ & $\mathrm{x}$ & $x$ \\
\hline & 144.72 & 919B-8H-5, 122-124 & $x$ & $x$ & $x$ & $\mathrm{x}$ & $x$ & $x$ & $x$ & $x$ & $x$ & & $\mathrm{x}$ \\
\hline 世 & 145.67 & 919B-8H-6, 67-69 & $\mathrm{x}$ & $\mathrm{x}$ & $x$ & $\mathrm{x}$ & $\mathrm{x}$ & $\mathrm{x}$ & $\mathrm{x}$ & $\mathrm{x}$ & $\mathrm{x}$ & & $\mathrm{x}$ \\
\hline
\end{tabular}

Figure 6. Mineral composition of sediments from Site 919. $\mathrm{Sm}=$ smectite, $\mathrm{Ka}=$ kaolinite, $\mathrm{It}=$ illite, $\mathrm{Ch}=$ chlorite, $\mathrm{Qt}=$ quartz, $\mathrm{Am}=$ amphibole, $\mathrm{Pl}=$ plagioclase, $\mathrm{Af}=$ alkali feldspar, $\mathrm{Ze}=$ zeolite, $\mathrm{Ca}=$ calcite, $\mathrm{Py}=$ pyroxene $\mathrm{x}$ $=$ present $; \mathrm{t}=$ present in trace amount.

that the basaltic edifice was breached by rivers (see Saito, this volume).

\section{Oligocene}

The starved Irminger Basin of the middle and late Eocene was fed by the input of coarse siliciclastic turbidites beginning in the late Oligocene (Shipboard Scientific Party, 1994a). Lithologic Unit III records the approach of a deep-sea fan toward Site 918, with the deposition of coarse, massive gravels in channels. Because this lithologic unit fines upward over two cycles, it suggests a middle fan environment of deposition (Mutti and Ricci-Lucchi, 1978). This unit shows an increase in chlorite, illite, and kaolinite at its base, with kaolinite levels declining near the top (Fig. 2). Smectite is still the dominant clay mineral.

At the beginning of the late Oligocene, eustatic sea level dropped considerably (Haq et al., 1987). A eustatic drop in sea level lowers the regional base level, effectively increasing the rate of erosion. If faster rates of erosion allow chlorite and illite to be deposited and preserved before they can be eliminated by the effects of hydrolysis, then increasing the rate of erosion, and thus the rate of deposition, may account for the increased amount of chlorite and illite deposited in these sediments at this time. Shipboard observations indicate high accumulation rates during this interval (Shipboard Scientific Party, 1994a). Turbidite deposition is also associated with low sea-level stands.

An alternative or additional explanation for the increased amounts of chlorite and illite in this interval may be that during this time the Earth was experiencing a global cooling event associated with the beginning of Antarctic continental glaciation (Barron et al., 1991). This cooling is apparently reflected in the clay-mineral assemblage of Site 918. Additional support for this hypothesis is the disappearance of gibbsite in lower Oligocene shelf sediments recovered during Leg 152 (see Holmes, this volume). Gibbsite, an aluminum hydroxide, is a warm climate indicator, suggesting intense weathering, and its disappearance at this time is probably also a result of the cooling trend. Further, the disappearance of kaolinite from the top of this unit may also be a result of cooling in the region.

\section{Miocene}

Kaolinite appears again in the lower Miocene calcareous pelagic sediment of lithologic Unit II. There is a noticeable increase from $\sim 4 \%$ to $13 \%$ above 764 mbsf, indicating a climatic warming trend beginning in the early to middle Miocene. A warming trend during this time has also been suggested by Wolfe and Poore (1982), who used the physiognomy of land flora in the Pacific Northwest, along with deep-sea records, to infer a temperature high for the Neogene during the middle Miocene. Also occurring in the sediments of the middle Miocene are noticeable increases in chlorite content and, to a lesser extent, increased illite content. These pulses may be representative of the short-term changes in eustatic sea level that occurred during this time (Haq et al., 1987).

The boundary separating lithologic Units I and II roughly corresponds to an "inversion point" where smectite content becomes increasingly less important uphole and illite content becomes increasingly dominant. This transition reflects a regional cooling trend that begins in the late Miocene.

\section{Glauconitic Hardgrounds}

The longer glauconitic material is exposed on the seafloor, the more $\mathrm{K}$ uptake can occur and the lower the expandability of the 10 / $17 \AA$ mineral thus formed (Odin and Matter, 1981). Odin and Matter have shown a relationship between $10 / 17 \AA$ mineral expandability and duration of hiatus by analyzing modern glaucony from localities around the world. The high expandability of the $10 / 17 \AA$ mineral forming the hardgrounds indicates a hiatus of short duration, or less time for $\mathrm{K}$ uptake, on the order of thousands to tens of thousands of years (Odin and Matter, 1981), well below the resolution of any absolute dating method for sediment of this age.

\section{Late Miocene to Holocene}

Although not quantified for this study, the non-clay minerals found in the $<2 \mu \mathrm{m}$ size fraction show a large increase in abundance (as noted by peak intensity) in lithologic Unit I. Amphibole is present in the $<2 \mu \mathrm{m}$ size fraction only in lithologic Unit I and is not observed below 635 mbsf (Figs. 5, 7). Quartz and feldspars are found much deeper in the hole but only in trace amounts, as indicated by very weak peak intensities. We propose that these represent eolian input. Near the middle of lithologic Unit I, the intensity of these peaks is increased (Fig. 7). This increase in the abundance of non-clay minerals in the clay size fraction is probably the result of glacial grinding of these minerals on the continent into glacial rock flour, which was subsequently transported to and deposited in the sea by melting icebergs or by turbidity currents. The first dropstones indicating the on- 

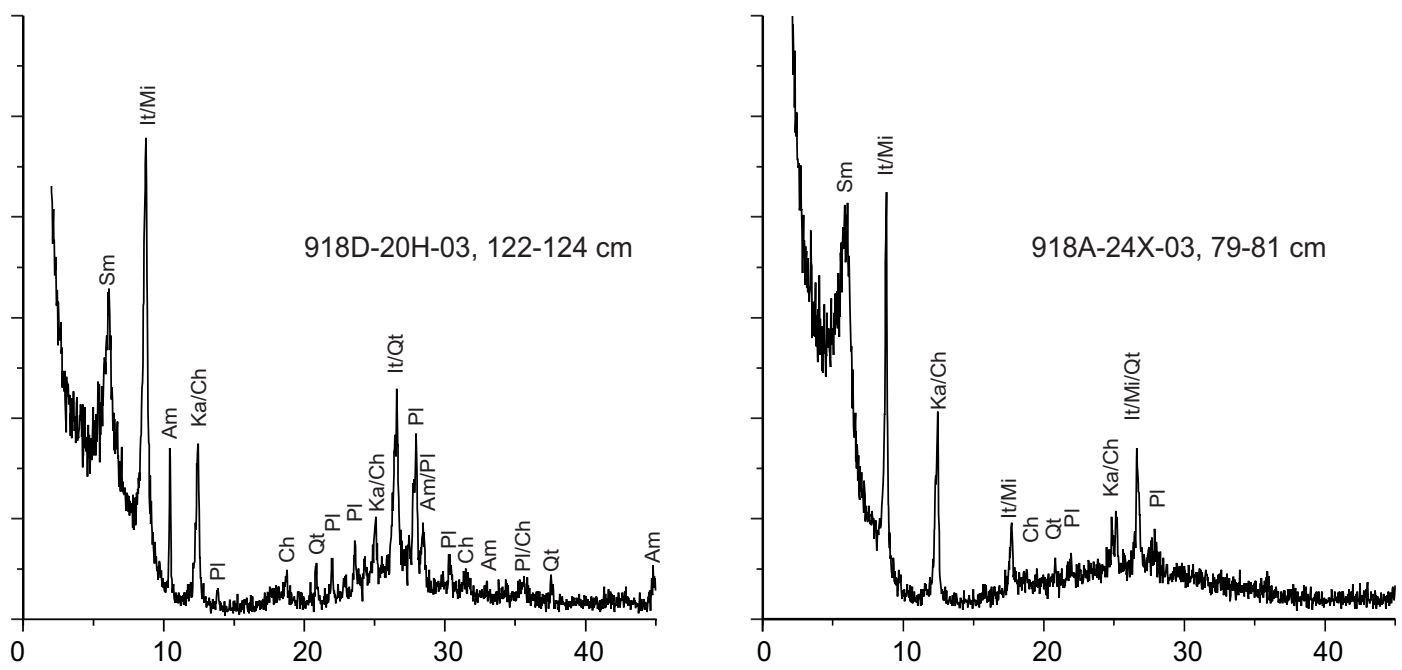

Figure 7. Diffractograms illustrating increase in intensity of non-clay minerals in lithologic Unit I. Vertical axis = intensity, counts per second (CPS). Horizontal axis $={ }^{\circ} 2 \theta$. Left: Sample 152-918D-20H-3, 122-124 cm. Air-dried sample from glacially influenced hemipelagic mud, Pliocene age. Sm $=$ smectite, It $/ \mathrm{Mi}=$ illite/mica, $\mathrm{Am}=$ amphibole, $\mathrm{Ka}=$ kaolinite, $\mathrm{Ch}=$ chlorite, $\mathrm{Pl}=$ plagioclase, $\mathrm{Qt}=$ quartz. Right: Sample 152-918D-24X-3, 79-81 cm, Pliocene age. Typical diffractogram of air-dried sample from lithologic Unit II, a hemipelagic mud.

set of Greenland glaciation (Larsen et al., 1994; Shipboard Scientific Party, 1994a) at Site 918 were found at 543 mbsf, just above the first appearance of amphibole in the $<2 \mu \mathrm{m}$ size fraction.

The relative abundances of the clay minerals in lithologic Unit I are variable. Illite is the dominant clay mineral with significant amounts of chlorite, kaolinite, and smectite. The large amounts of illite and chlorite indicate that dominantly physical processes produced the clay-mineral assemblage. The ubiquitous presence of the warm-climate indicator, kaolinite, throughout the interval is not compatible with these cold-climate indicators. Thus, it is probably present as reworked kaolinite from older sediment on Greenland and was eroded and redeposited in the Irminger Basin as suggested by Krissek (1989) for the presence of kaolinite at Sites 642 and 643 in the Norwegian Sea.

\section{Results of Factor Analysis}

The high percentage of variance accounted for by factor 1 (65\%) suggests that this factor had the largest influence over the resulting clay-mineral assemblages at Site 918. The loadings for factor 1 (Fig. 4) are strongly positive below $450 \mathrm{mbsf}$, with most values close to 1.0. The high positive coefficient for smectite (Table 4) indicates that weathered basaltic landmasses, and possibly in situ alteration of volcanogenic material, were the prime sources of clay material throughout the history of Site 918 up until early Pliocene time. This provenance supplied mostly smectite (Fig. 4). Such landmasses are common in the area (Shipboard Scientific Party, 1994a; 1994b). Leg 152 sailed to the east Greenland margin, in part, because of the unusually large amounts of basalt that were erupted onto the adjacent continents during the early formation of the Irminger Basin, in early Paleocene time (Larsen et al., 1994).

A major change, at approximately $457 \mathrm{mbsf}$, is indicated by increasingly variable factor 1 loading values (Fig. 4). This change coincides with increased levels of chlorite and illite in the assemblage and indicates the influence of a continental (vs. basaltic) landmass dominated by physical weathering (i.e., the glaciated Greenland landmass). This input alternates rhythmically (Fig. 4) and may coincide with southeast Greenland's glacial/interglacial periods.

Although concrete evidence for an earlier beginning of southeast Greenland glaciation ( 7 Ma) is provided by dropstones (Fig. 2) and IRD (Larsen et al., 1994; Shipboard Scientific Party, 1994a), glaciation was not recorded by changes in the clay-mineral assemblages of
Site 918 until the Pliocene, as recorded by a decreasing supply of smectite relative to the other clay minerals. This suggests that the provenance and/or delivery mechanism for sand and coarser detritus is not coupled with that for the clay-sized sediment. In other words, the smectite-supplying factor overwhelmed the chlorite-illite supplying factor (presumably icebergs) until the Pliocene. The sand supply recorded the onset of glaciation earlier than the clays because there was no factor supplying much sand to Site 918 after the OligoceneMiocene fan deposition was cut off and before icebergs rafted sand to the area.

The high positive component loading for illite and the high negative loading for kaolinite in factor 2 (Table 4) suggest that factor 2 reflects a "continental" or "felsic" source area as opposed to the basaltic source area reflected by factor 1 . Factor 2 loadings generally increase uphole, with the most significant change again occurring above 457 mbsf (Fig. 4). Below this depth, loadings are predominantly negative, and above this depth loadings are predominantly positive. This shift again probably reflects the increasing importance of glaciation on the clay-mineral assemblage, causing relatively higher concentrations of illite and lower concentrations of kaolinite, and may indicate the glacial erosion of illite-rich, pre-Cenozoic shales.

The high positive component loadings for kaolinite and high negative loadings for chlorite in factor 3 appear to reflect a climatic signal. The loadings of factor 3 generally decrease uphole, reflecting a decreasing importance of kaolinite relative to an increasing importance of chlorite (Fig. 4). This chlorite-kaolinite relationship reflects a prevailing change in climate associated with glaciation, where the negative values above $457 \mathrm{mbsf}$ reflect the importance of chlorite related to glaciation, and the positive values reflect warmer conditions, more favorable to the production of kaolinite.

Factors 1 and 2 (reflecting provenance and mode of transport) together account for $93 \%$ of the total variance, while factor 3 (reflecting climate) accounts for only $7 \%$. These results suggest that the main factor determining clay composition at Site 918 is not climate, but provenance, and to a lesser extent, mode of transport. However, it also appears that a climatic signal is recorded in the clay minerals (factor 3), but as a much weaker signal.

\section{Site 919}

The clay-mineral assemblage at Site 919 is similar to the upper Pliocene-Pleistocene section in lithologic Unit I from Site 918, with 
the exception that below the first 20 m of sediment, smectite has a much higher relative abundance than illite (Figs. 2, 3). Clay minerals can show lateral variations in their abundance in the direction of transport (Parham, 1966). Kaolinite tends to be more concentrated near the shore. Illite increases basinward, and smectite is generally found in greater concentrations farther basinward than illite. The increased amount of smectite at Site 919 relative to Site 918 is probably indicative of these variations and indicates a roughly west to east direction of transport.

\section{SUMMARY AND CONCLUSIONS}

Samples from ODP Leg 152 Sites 918 and 919 were analyzed for grain-size distribution and mineral composition of the $<2 \mu \mathrm{m}$ size fraction. Relative abundances of the clay minerals were determined by use of an oriented internal standard. The vertical changes in the relative abundances of the clay minerals were subjected to statistical analysis using Pearson correlation and factor analysis. Significant relationships among the mineral species, loadings from factor analysis, as well as presence/absence data were used to infer paleoclimatic changes in the North Atlantic.

Factor analysis indicated that the supply of smectite to Site 918 was overwhelmingly the most important contributing factor to the resulting clay-mineral assemblages until Pliocene time. Weathering of basaltic landmasses and volcanogenic materials were the main sources for clay minerals supplied to Site 918 from the middle Eocene to the Pliocene. Decreasing importance of smectite supply relative to the other clay minerals, in Pliocene time, along with increasing amounts of illite relative to kaolinite, and increasing amounts of chlorite relative to kaolinite, record the influence of Greenland's glaciation on the clay-mineral composition in the Irminger Basin.

Smectite is the dominant clay mineral through most of the sequence, particularly in pre-Pliocene sediment. The presence of smectite and kaolinite indicates warm conditions during the Eocene, with chemical weathering the primary clay-producing process. The absence of illite and chlorite suggests a warm period at this time. Increasing illite and chlorite contents in the Oligocene reflect a global cooling event. Miocene sediments record an increase in kaolinite, indicating a warming trend beginning in the early to middle Miocene. This warming trend is then followed by a cooling trend in the late Miocene, indicated by the increased amounts of illite and a simultaneous decrease in smectite. A series of glauconitic hardgrounds heralds the decline of chalk deposition in the basin. These hardgrounds represent hiatuses of short duration, with dissolution of kaolinite and zeolites to form the highly expandable $10 / 17 \AA$ mineral. Increased amounts of non-clay minerals in the $<2 \mu \mathrm{m}$ size fraction (rock-flour), beginning in late Miocene time, indicate the onset of Greenland glaciation. Kaolinite found in these sediments is probably reworked from older rocks and thus not indicative of climatic conditions at this time.

\section{ACKNOWLEDGMENTS}

This study was carried out as part of Heiden's Master's Thesis research at the University of Nebraska-Lincoln. Brandon Wilken and Justin Spence helped in the preparation of samples. Thanks also go to Dr. David K. Watkins, whose knowledge and advise were most helpful. We also wish to thank Annabelle Foos, Larry Krissek, and Woody Wise for their careful review of this manuscript and for many helpful comments.

This project has been funded in part by a grant from the Joint Oceanographic Institutions/U.S. Science Support Program.

\section{REFERENCES}

Barron, J., Larsen, B., and Baldauf, J.G., 1991. Evidence for late Eocene to early Oligocene Antarctic glaciation and observations on late Neogene glacial history of Antarctica: results from Leg 119. In Barron, J., Larsen,
B., et al., Proc. ODP, Sci. Results, 119: College Station, TX (Ocean Drilling Program), 869-891.

Biscaye, P.E., 1964. Distinction between kaolinite and chlorite in recent sediments by X-ray diffraction. Am. Miner., 49:1281-1289.

_ 1965. Mineralogy and sedimentation of recent deep-sea clays in the Atlantic Ocean and adjacent seas and oceans. Geol. Soc. Am. Bull., 76:803-832.

Borg, I.Y., and Smith, D.K., 1969. Calculated x-ray powder patterns for silicate minerals. Mem.-Geol. Soc. Am., 122.

Brown, G., and Brindley, G.W., 1980. X-ray diffraction procedures for clay mineral identification. In Brindley, G.W., and Brown, G. (Eds.), Crystal Structures of Clay Minerals and Their X-ray Identification. Mineral. Soc. Monogr. London, 5:305-359.

Chamley, H., 1979. North-Atlantic clay sedimentation and palaeoenvironment since the Late Jurassic. In Talwani, M., Hay, W., and Ryan, W.B.F. (Eds), Deep Drilling Results in the Atlantic Ocean: Continental Margins and Paleoenvironment. Am. Geophys. Union, Maurice Ewing Ser., 3:342-361

- 1989. Clay Sedimentology: Berlin (Springer-Verlag).

Cremer, M., Maillet, N., and Latouche, C., 1989. Analysis of sedimentary facies and clay mineralogy of the Neogene-Quaternary sediments in ODP Site 646, Labrador Sea. In Srivastava, S.P., Arthur, M.A., Clement, B., et al., Proc. ODP, Sci. Results, 105: College Station, TX (Ocean Drilling Program), 71-81.

Darby, D.A., 1975. Kaolinite and other clay minerals in Arctic Ocean sediments. J. Sediment. Petrol., 45:272-279.

Drever, J.I., 1973. The preparation of oriented clay mineral specimens for Xray diffraction analysis by a filter-membrane peel technique. Am. Mineral., 58:553-554.

Eslinger, E.V., Mayer, L.M., Durst, T.L., Hower, J., and Savin, S.M., 1973. An $\mathrm{x}$-ray technique for distinguishing between detrital and secondary quarty in the fine-grained fraction of sedimentary rocks. J. Sediment. Petrol., 43:540-543.

Froget, C., Desprairies, A., Latouche, C., and Maillet, N., 1989. Paleoenvironmental significance of Cenozoic clay deposits from the Norwegian Sea: ODP Leg 104. In Eldholm, O., Thiede, J., Taylor, E., et al., Proc. ODP, Sci. Results, 104: College Station, TX (Ocean Drilling Program), 41-60.

Griffin, J.J., Windom, H., and Goldberg, E.D., 1968. The distribution of clay minerals in the World Ocean. Deep-Sea Res. Part A, 15:433-459.

Haq, B.U., Hardenbol, J., and Vail, P.R., 1987. Chronology of fluctuating sea levels since the Triassic. Science, 235:1156-1167.

Jackson, M.L., 1975. Soil Chemical Analysis-Advanced Course (2nd ed.): Madison, WI (Self-published).

Krissek, L.A., 1989. Bulk mineralogy of nonbiogenic sediments from ODP Sites 642 and 643, Norwegian Sea: implications for sediment provenance and recycling. In Eldholm, O., Thiede, J., Taylor, E., et al., Proc. ODP, Sci. Results, 104: College Station, TX (Ocean Drilling Program), 29-39.

Larsen, H.C., Saunders, A.D., Clift, P.D., Beget, J., Wei, W., Spezzaferri, S., and the ODP Leg 152 Scientific Party, 1994. Seven million years of glaciation in Greenland. Science, 264:952-955.

Moore, D.M., and Reynolds, R.C., Jr., 1989. Quantitative analysis. In Moore, D.M., and Reynolds, R.C., Jr. (Eds.), X-Ray Diffraction and the Identification and Analysis of Clay Minerals: Oxford (Oxford Univ. Press), 272-309.

Mumpton, F.A., 1960. Clinoptilolite redefined. Am. Mineral., 45:351-369.

Mutti, E., and Ricci-Lucchi, F., 1978. Turbidites from the northern Apennines: introduction to facies analysis. Int. Geol. Rev., 20:125-166.

Naidu, A.S., Burrell, D.C., and Hood, D.W., 1971. Clay mineral composition and geologic significance of some Beaufort Sea sediments. J. Sediment. Petrol., 41:691-694.

Nielsen, O.B., Cremer, M., Stein, R., Thiébault, F., and Zimmerman, H., 1989. Analysis of sedimentary facies, clay mineralogy, and geochemistry of the Paleogene sediments of Site 647, Labrador Sea. In Srivastava, S.P., Arthur, M.A., Clement, B., et al., Proc. ODP, Sci. Results, 105: College Station, TX (Ocean Drilling Program), 101-110.

Odin, G.S., and Matter, A., 1981. Die glauconarium origine. Sedimentology, 28:611-643.

Parham, W.E., 1966. Lateral variations of clay mineral assemblages in modern and ancient sediments. Proc. Int. Clay Conf., 1:135-145.

Rateev, M.A., Gorbunova, Z.N., Lisitzyn, A.P., and Nosov, G.L., 1969. The distribution of clay minerals in the oceans. Sedimentology, 13:21-43.

Reynolds, R.C., Jr., 1980. Interstratified clay minerals. In Brindley, G.W., and Brown, G. (Eds.), Crystal Structures of Clay Minerals and Their Xray Identification. London Mineral. Soc. Monogr., 5:249-304. 
Rohlf, J.F., and Sokal, R.R., 1969. Statistical Tables: San Francisco (W.H. Freeman).

Shipboard Scientific Party, 1994a. Site 918. In Larsen, H.C., Saunders, A.D., Clift, P.D., et al., Proc. ODP, Init. Repts., 152: College Station, TX (Ocean Drilling Program), 177-256.

- 1994b. Site 919. In Larsen, H.C., Saunders, A.D., Clift, P.D., et al., Proc. ODP, Init. Repts., 152: College Station, TX (Ocean Drilling Program), 257-277.

Singer, A., 1984. The paleoclimatic interpretation of clay minerals in sediments: a review. Earth-Sci. Rev., 21:251-293.

Thiébault, F., Cremer, M., Debrabant, P., Foulon, J., Nielsen, O.B., and Zimmerman, H., 1989. Analysis of sedimentary facies, clay mineralogy, and geochemistry of the Neogene-Quaternary sediments in Site 645, Baffin Bay. In Srivastava, S.P., Arthur, M.A., Clement, B., et al., Proc. ODP, Sci. Results, 105: College Station, TX (Ocean Drilling Program), 83100.

Timofeev, P.P., Renngarten, N.V., and Bogloyubova, L.J., 1978. Lithology and clay mineralogy of the sediments from Site 336, DSDP Leg 38. In
Talwani, M., Udintsev, G., et al., Init. Repts. DSDP, 38 (Suppl.): Washington (U.S. Govt. Printing Office), 9-19.

Timofeev, P.P., Renngarten, N.V., Rateev, M.A., and Eremeev, V.V., 1979. Clay minerals of sediments from DSDP Leg 49. In Luyendyk. B.P. Cann, J.R., et al., Init. Repts. DSDP, 49: Washington (U.S. Govt. Printing Office), 443-445.

Wolfe, J.A., 1978. A paleobotanical interpretation of Tertiary climates in the Northern Hemisphere. Am. J. Sci., 66:694-703.

Wolfe, J.A., and Poore, R.Z., 1982. Tertiary marine and nonmarine climatic trends. In Berger, W.H., and Crowell, J.C. (Eds.), Climate In Earth History. Nat. Acad. Sci. U.S., 154-158.

Date of initial receipt: 6 November 1995

Date of acceptance: 29 May 1996

Ms 152SR-248 